\title{
The GW182 protein colocalizes with mRNA degradation associated proteins hDcp1 and hLSm4 in cytoplasmic GW bodies
}

\author{
THEOPHANY EYSTATHIOY, ${ }^{1}$ ANDREW JAKYMIW, ${ }^{2}$ EDWARD K.L. CHAN, ${ }^{2}$ BERTRAND SÉRAPHIN, ${ }^{3}$ \\ NICOLAS COUGOT, ${ }^{3}$ and MARVIN J. FRITZLER ${ }^{\mathbf{1}}$ \\ ${ }^{1}$ Departments of Medicine and Biochemistry and Molecular Biology, University of Calgary, Calgary, Alberta T2N 4N1, Canada \\ ${ }^{2}$ Department of Oral Biology, University of Florida, Gainesville, Florida 32611, USA \\ ${ }^{3}$ Centre de Génétique Moléculaire, CNRS, Yvette, France
}

\begin{abstract}
A novel cytoplasmic compartment referred to as GW bodies (GWBs) was initially identified using antibodies specific to a 182-kD protein termed GW182. GW182 was characterized by multiple glycine(G)-tryptophan(W) repeats and an RNA recognition motif (RRM) that bound a subset of HeLa cell messenger RNAs (mRNAs). The function of GWBs was not known; however, more recent evidence suggested similarities between GWBs and cytoplasmic structures that contain hLSm proteins and hDcp1, the human homolog to a yeast decapping enzyme subunit. In this study, we used antibodies to hLSm4 and hDcp1 to show that both of these markers of an mRNA degradation pathway colocalize to the same structures as GW182. Our studies demonstrate that GW182, hLSm4, and hDcp1 are found in the same cytoplasmic structures and suggest that GW182 is involved in the same mRNA processing pathway as hLSm4 and hDcp1.
\end{abstract}

Keywords: mRNA; degradation; decapping; GW bodies; LSm

\section{INTRODUCTION}

A novel protein GW182, named for the presence of multiple glycine $(\mathrm{G})$-tryptophan(W) repeats and for its molecular mass of $182 \mathrm{kD}$, was localized by indirect immunofluorescence and immunoelectron microscopy to distinct foci within the cytoplasm (Eystathioy et al. 2002a). This protein, which harbors an RNA recognition motif (RRM), was demonstrated to bind a discrete subset of mRNAs from HeLa cells. Because colocalization studies showed that the cytoplasmic structures containing GW182 were distinct from the Golgi complex, lysosomes, endosomes, and others, they were named GW bodies or GWBs. Recently, discrete cyto-

Reprint requests to: Marvin J. Fritzler, Professor, Faculty of Medicine: HRB410B, University of Calgary, 3330 Hospital Dr. NW, Calgary, AB, T2N 4N1 Canada; e-mail: fritzler@ucalgary.ca; fax: (403) 283-5666.

Abbreviations: ARE, AU rich elements; ARED, AU rich element database; DAPI, 4',6-diamidino-2-phenylindole; FRAP, fluorescence resonance after photobleaching; GWBs, glycine tryptophan rich cytoplasmic structures; $\mathrm{hDcp}$, human homolog to a yeast decapping enzyme subunit; IIF, indirect immunofluorescence; IP, immunoprecipitation; LSm, like Sm; mAb, monoclonal antibody; NHS, normal human serum; PBS-T, phosphate buffered saline containing Tween 20; TnT, transcription and translation.

Article and publication are at http://www.rnajournal.org/cgi/doi/ 10.1261/rna.5810203. plasmic foci that contained hLSm complex proteins $1-7$, as well as the hDcp 1 protein were described and interestingly, cytoplasmic foci containing these proteins resembled GWBs (Ingelfinger et al. 2002; van Dijk et al. 2002). Both the hLSm1-7 complex (Bouveret et al. 2000; Tharun et al. 2000; Tharun and Parker 2001) and hDcp (Dunckley and Parker 1999, 2001; van Dijk et al. 2002) are believed to be involved in mRNA decapping and other processes of mRNA degradation. In mammalian cells, decapping has been suggested to be an important step in the process of mRNA decay (Couttet et al. 1997; Gao et al. 2001). Taken together, these observations suggest that the GW182 protein and GWBs are involved in mRNA metabolism and, more specifically, GWBs may be functional sites within the cytoplasm involved in mRNA degradation. In this study, we demonstrate that the hLSm4 protein, a component of the hLSm1-7 complex, and the hDcpl protein colocalize with GW182 in GWBs. The data suggests that GWBs are involved in mRNA degradation.

\section{RESULTS AND DISCUSSION}

Recent reports have indicated that certain mRNAs and mRNA-processing molecules are localized in distinct cyto- 
plasmic foci (Tharun and Parker 2001; Eystathioy et al. 2002b; van Dijk et al. 2002). Two proteins of the heptameric hLSm complex, hLSm1 and hLSm4 were among the proteins localized to such foci (Ingelfinger et al. 2002). The heptameric LSm complex exists as two entities, the LSm2-8 complex that is involved in mRNA splicing (Séraphin 1995; Achsel et al. 1999; Mayes et al. 1999; Salgado-Garrido et al. 1999) and the LSm1-7 complex that is involved in mRNA degradation (Bouveret et al. 2000; Tharun et al. 2000; Denegri et al. 2001; Tharun and Parker 2001). To examine whether GWBs are involved in the mRNA decay pathways, IIF colocalization reactions were performed using a rabbit antibody specific to the carboxyl terminus of the hLSm4 protein. The majority of cytoplasmic structures marked by the index human serum specific for GWBs were colocalized to the staining produced by the rabbit anti-hLSm 4 antibodies (Fig. 1A). Furthermore, the mouse monoclonal antibody $4 \mathrm{~B} 6$ that is specific for the GW182 protein (Eystathioy et al. 2003) also colocalized with the hLSm4 protein (Fig. 1B). In yeast, LSAm1-7 proteins were shown previously to associate with a subunit of the decapping enzyme Dcp1 as well as the exonuclease Xrn1p (Bouveret et al. 2000; Tharun et al. 2000). On the basis of these observations, we reasoned that GWBs may also be involved in mRNA decay and initiated studies to determine whether hDcpl, the human homolog of the yeast decapping enzyme subunit Dcp1, was also present in HEp-2 cell GWBs. An overlap between the cytoplasmic structures stained by rabbit anti-hDcp 1 antibodies (van Dijk et al. 2002) and the index human serum specific for GWBs (Fig. 1C) was observed. These observations were supported by studies showing that the mAb $4 \mathrm{~B} 6$ antiGW182 also colocalized with the hDcp1 protein (Fig. 1D). The colocalization observed between the hLSm4 protein and the GWBs was a not a result of cross-reacting antibodies, as determined by immunoprecipitation assays using radiolabeled hLSm4 and GW182 proteins and by Western blot analysis using cell extracts probed with rabbit antihLSm4 antibody, rabbit anti-hDcp1 antibody, and the index human serum (data not shown).

In this study, we provide evidence that the recently identified mRNA-binding protein GW182-enriched cytoplasmic bodies (Eystathioy et al. 2002a) also contain hDcpl and hLSm4. Taken together, the data provides a basis for the postulate that the RRM-bearing GW182 may be involved in shuttling of mRNA to the GWBs, and that the GWBs, along with the mRNA decapping enzymes, may represent sites of mRNA decay. Recent evidence in yeast has described a major pathway of eukaryotic messenger RNA (mRNA) turnover that begins with deadenylation, followed by decapping and $5^{\prime}$ to $3^{\prime}$ exonucleolytic decay that occurred in discrete cytoplasmic foci called processing bodies (P bodies) (Sheth and Parker 2003). It may be that the P bodies in yeast are analogous to GWBs in mammalian cells. In mammalian cells, mRNAs might localize to the GWBs as part of surveillance and proof-reading processes that include the de-

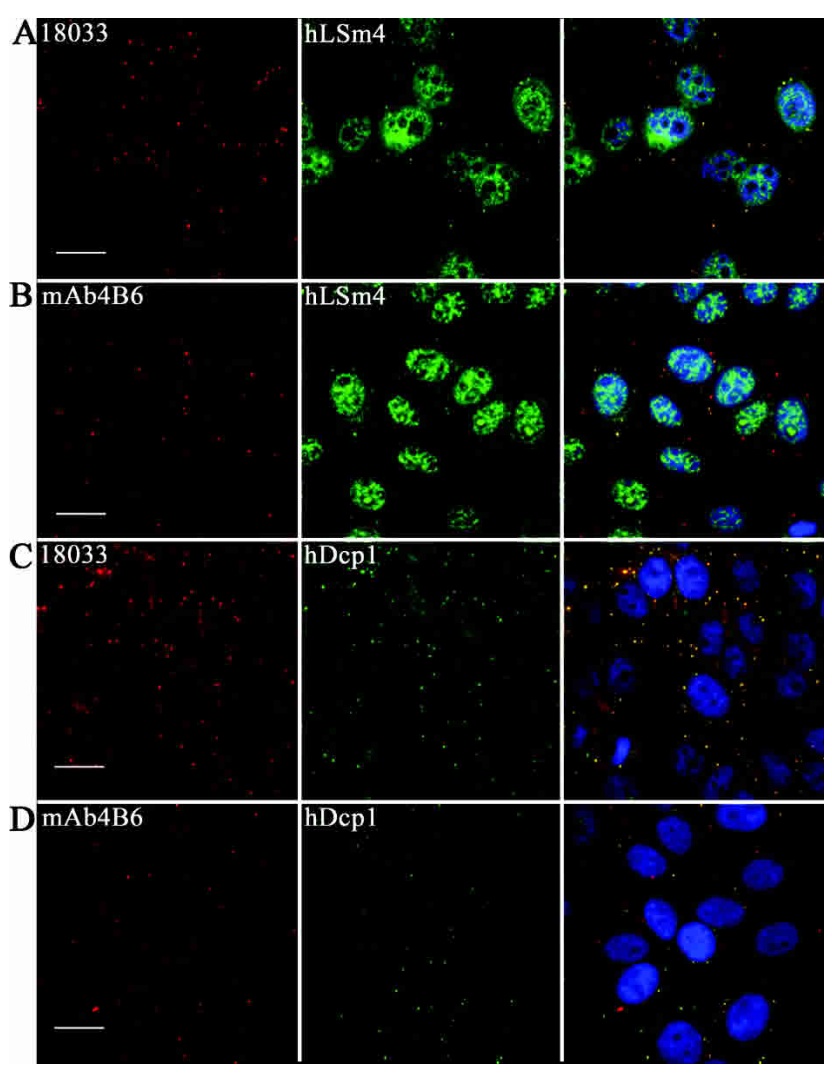

FIGURE 1. Indirect immunofluorescence (IIF) studies demonstrating that GW bodies colocalize with LSm4 and hDcp1 in HEp-2 cells (Immuno Concepts Inc.) were performed as described previously (Eystathioy et al. 2002a). (A) Cytoplasmic bodies detected with the index human serum \#18033 (diluted 1/600) and rabbit anti-hLSm4 antibodies (diluted 1/200). (B) Staining with the mAb anti-GW182 4B6 and rabbit anti-hLSm4 antibodies (diluted 1/200). (C) Staining with the index patient serum \#18033 (1/600 dilution) and rabbit anti-hDcp1 antibodies (diluted 1/600). (D) IIF using the mAb $4 \mathrm{~B} 6$ and the rabbit anti-hDcp1 antibodies (diluted 1/600). The secondary antibodies included Cy3-conjugated anti-human (IgG) and anti-mouse (IgG) antibodies (shown in the first column) and FITC-conjugated anti-rabbit IgG antibodies (shown in the second column). The merged images are shown in the third column, which includes the DAPI-stained nuclei. The scale bars in the left column are equal to $10 \mu \mathrm{m}$. The nuclei of cells were stained with DAPI dissolved in glycerol mounting medium (VectaShield: Vector Laboratories).

capping activity of hDcp1 and the hLSm1-7 complex. (Wilusz et al. 2001; Vasudevan et al. 2002).

On the basis of our observations that GW182 protein is phosphorylated (Eystathioy et al. 2002a), GW182 may also be regulated through some cell-signaling pathway that may affect mRNA stability. One putative signaling pathway may be the p38 MAPK pathway, which is required for the stabilization of some mRNAs containing AU-rich elements (AREs) (Winzen et al. 1999; Bollig et al. 2003).

In summary, the observation that GW182 protein is localized to the same cytoplasmic compartment as hLSm4 and $\mathrm{hDcp} 1$ proteins suggests that it also plays a key role in mRNA decay and degradation. These observations elucidate the emerging theme of coordinated mRNA regulation, 
whereby mRNA-binding proteins have been found to associate with different and discrete subsets of mRNAs from a total mRNA population (Takizawa et al. 2000; Keene and Tenenbaum 2002). It is becoming clear that some of these mRNA-binding proteins are involved in controlling and targeting mRNA expression, whereas others are involved in pathways of mRNA scanning, proof-reading, and degradation.

\section{ACKNOWLEDGMENTS}

We acknowledge the technical assistance of John Hamel. This work was supported in part by the Canadian Institutes for Health Research Grant MOP-57674 and the National Institutes of Health Grants AI47859 and AI39645. M.J.F. holds the Arthritis Society Chair at the University of Calgary.

The publication costs of this article were defrayed in part by payment of page charges. This article must therefore be hereby marked "advertisement" in accordance with 18 USC section 1734 solely to indicate this fact.

Received May 1, 2003; accepted July 7, 2003.

\section{REFERENCES}

Achsel, T., Brahms, H., Kastner, B., Bachi, A., Wilm, M., and Luhrmann, R. 1999. A doughnut-shaped heteromer of human Sm-like proteins binds to the $3^{\prime}$-end of U6 snRNA, thereby facilitating U4/U6 duplex formation in vitro. EMBO J. 18: 5789-5802.

Bollig, F., Winzen, R., Gaestel, M., Kostka, S., Resch, K., and Holtmann, H. 2003. Affinity purification of ARE-binding proteins identifies poly(A)-binding protein 1 as a potential substrate in MK2-induced mRNA stabilization. Biochem. Biophys. Res. Commun. 301: 665-670.

Bouveret, E., Rigaut, G., Shevchenko, A., Wilm, M., and Séraphin, B. 2000. A Sm-like protein complex that participates in mRNA degradation. EMBO J. 19: 1661-1671.

Couttet, P., Fromont-Racine, M., Steel, D., Pictet, R., and Grange, T. 1997. Messenger RNA deadenylation precedes decapping in mammalian cells. Proc. Natl. Acad. Sci. 94: 5628-5633.

Denegri, M., Chiodi, I., Corioni, M., Cobianchi, F., Riva, S., and Biamonti, G. 2001. Stress-induced nuclear bodies are sites of accumulation of pre-mRNA processing factors. Mol. Biol. Cell 12: 3502-3514.

Dunckley, T. and Parker, R. 1999. The DCP2 protein is required for mRNA decapping in Saccharomyces cerevisiae and contains a functional MutT motif. EMBO J. 18: 5411-5422.

- 2001. Yeast mRNA decapping enzyme. Methods Enzymol. 342: 226-233.

Eystathioy, T., Chan, E.K.L., Tenenbaum, S.A., Keene, J.D., Griffith,
K.J., and Fritzler, M.J. 2002a. A phosphorylated cytoplasmic autoantigen, GW182, associates with a unique population of human mRNAs within novel cytoplasmic speckles. Mol. Biol. Cell 13: 1338-1351.

Eystathioy, T., Peebles, C., Hamel, J.C., Vaughan, J.H., and Chan, E.K.L. 2002b. Autoantibody to hLSm4 and the hepatameric LSm complex in anti-Sm sera. Arthritis Rheum. 46: 726-734.

Eystathioy, T., Chan, E.K.L., Mahler, M., Luft, L.M., Fritzler, M.L., and Fritzler, M.J. 2003. A panel of monoclonal antibodies to cytoplasmic GW bodies and the mRNA binding protein GW182. Hybridoma \& Hybridomics 22: 79-86.

Gao, M., Wilusz, C.J., Peltz, S.W., and Wilusz, J. 2001. A novel mRNAdecapping activity in HeLa cytoplasmic extracts is regulated by AU-rich elements. EMBO J. 20: 1134-1143.

Ingelfinger, D., Arndt-Jovin, D.J., Luhrmann, R., and Achsel, T. 2002. The human LSm1-7 proteins colocalize with the mRNA-degrading enzymes Dcpl/2 and Xrnl in distinct cytoplasmic foci. RNA 8: $1489-1501$.

Keene, J.D. and Tenenbaum, S.A. 2002. Eukaryotic mRNPs may represent post-transcriptional operons. Mol. Cell 9: 1161-1167.

Mayes, A.E., Verdone, L., Legrain, P., and Beggs, J.D. 1999. Characterization of Sm-like proteins in yeast and their association with U6 snRNA. EMBO J. 18: 4321-4331.

Salgado-Garrido, J., Bragado-Nilsson, E., Kandels-Lewis, S., and Séraphin, B. 1999. Sm and Sm-like proteins assemble in two related complexes of deep evolutionary origin. EMBO J. 18: 3451-3462.

Séraphin, B. 1995. Sm and Sm-like proteins belong to a large family: Identification of proteins of the U6 as well as the U1, U2, U4 and U5 snRNPs. EMBO J. 14: 2089-2098.

Sheth, U. and Parker, R. 2003. Decapping and decay of messenger RNA occur in cytoplasmic processing bodies. Science 300: 805-808.

Takizawa, P.A., DeRisi, J.L., Wilhelm, J.E., and Vale, R.D. 2000. Plasma membrane compartmentalization in yeast by messenger RNA transport and a septin diffusion barrier. John Hopkins University 290: 341-344.

Tharun, S. and Parker, R. 2001. Targeting an mRNA for decapping: Displacement of translation factors and association of the Lsm1p$7 \mathrm{p}$ complex on deadenylated yeast mRNAs. Mol. Cell 8: 10751083.

Tharun, S., He, W., Mayes, A.E., Lennertz, P., Beggs, J.D., and Parker, R. 2000. Yeast Sm-like proteins function in mRNA decapping and decay. Nature 404: 515-518.

van Dijk, E., Cougot, N., Meyer, S., Babajko, S., Wahle, E., and Séraphin, B. 2002. Human Dcp2: A catalytically active mRNA decapping enzyme located in specific cytoplasmic structures. $E M B O$ J. 21: 6915-6924.

Vasudevan, S., Peltz, S.W., and Wilusz, C.J. 2002. Non-stop decay-a new mRNA surveillance pathway. BioEssays 24: 785-788.

Wilusz, C.J., Wang, W., and Peltz, S.W. 2001. Curbing the nonsense: The activation and regulation of mRNA surveillance. Genes \& Dev. 15: 2781-2785.

Winzen, R., Kracht, M., Ritter, B., Wilhelm, A., Chen, C.Y., Shyu, A.B., Muller, M., Gaestel, M., Resch, K., and Holtmann, H. 1999. The p38 MAP kinase pathway signals for cytokine-induced mRNA stabilization via MAP kinase-activated protein kinase 2 and an AUrich region-targeted mechanism. EMBO J. 18: 4969-4980. 

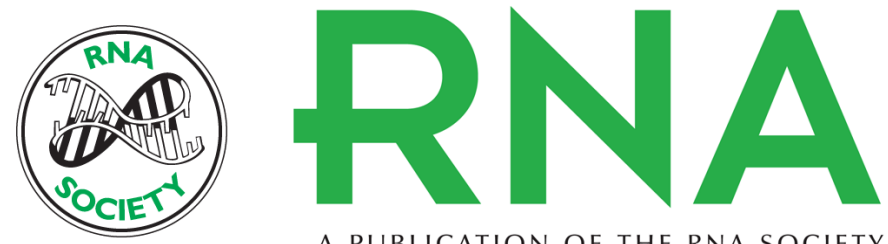

A PUBLICATION OF THE RNA SOCIETY

\title{
The GW182 protein colocalizes with mRNA degradation associated proteins hDcp1 and hLSm4 in cytoplasmic GW bodies
}

\author{
THEOPHANY EYSTATHIOY, ANDREW JAKYMIW, EDWARD K.L. CHAN, et al.
}

RNA 2003 9: 1171-1173

References This article cites 23 articles, 14 of which can be accessed free at:

http://rnajournal.cshlp.org/content/9/10/1171.full.html\#ref-list-1

\section{License}

Email Alerting

Receive free email alerts when new articles cite this article - sign up in the box at the Service top right corner of the article or click here.

To subscribe to $R N A$ go to:

http://rnajournal.cshlp.org/subscriptions 